\title{
DRAMA TECHNIQUES IN TEACHING ENGLISH AS A SECOND LANGUAGE TO UNIVERSITY STUDENTS
}

\author{
E.G. Shraiber, shraibereg@susu.ru, \\ E.N. Yaroslavova, yaroslavovaen@susu.ru \\ South Ural State University, Chelyabinsk, Russian Federation
}

\begin{abstract}
The article aims at topicality of drama techniques in teaching English as a second language at University which provides the basis for the development of linguistic and social skills of students as well as their personality and potentials.

The main goal of the article is to disclose benefits of applying the drama teaching method in foreign language teaching and foreign language learning. The special emphasis is made upon role-plays as one of the most powerful drama-based techniques to be used within the educational process at the University level.

The basic research methods to be used are academic literature review, periodicals analysis, observation and survey.

The authors focus on using drama teaching method as an integral part of students' professional education and provide the reader with the results of the experiment realized in the form of Mock Trial with the students of Law Faculty (SUSU).

Keywords: drama technique, foreign language teaching, foreign language learning, roleplay, mock trial.
\end{abstract}

\section{Introduction}

Nowadays the knowledge of foreign languages, especially English, is considered one of the key competences that enable the future professional to communicate in different social contexts. Moreover, intercultural professionallyoriented competence is believed to provide the basis for the personality self-fulfillment and, in the long run, self-realization. Therefore, the major task of educators is to create the productive teaching environment that implies the use of techniques stimulating learners' activity and developing their potential. Herein a question connected with the benefits of drama in foreign language teaching (FLT) and foreign language learning (FLL) at the University level arises. Although there are many studies about using drama to learn English the topic still generates controversy and needs further investigation.

\section{Why use drama techniques}

\section{in FLL and FLT?}

The idea to use drama techniques in education dates back to the 1950s. It was presumed that when participants were engaged in more spontaneous, improvised work (traditionally called "drama") their level of engagement and feeling would be more intense and "genuine" than when they were performing on stage (traditionally called "theatre") [8]. The emphasis was made on the personal growth of the individual through creative self-expression. Early advocates of drama in education assumed that all learners had the inclination to engage in dramatic play and based their approaches on the minimal intervention of the teacher. Even in the recent history of drama teaching one can find it as a dynamically developed process that encourages personal growth and self-expression of learners [8].

The word "drama" comes from Greek, meaning "action" or "a play". "Drama" is not an easy term to define. It is often confused with "theatre". Researchers compare it with a blanket term covering "a wide range of oral activities that have an element of creativity present" (Hubbard et al 1986: 317) [3], but above "all it should be a communicative activity where the student makes the choice" [3].

In our research we differentiate these terms and treat "theatre" to be largely concerned with communication between actors and an audience; whereas "drama" to be largely concerned with experience by the participants, irrespective of any function of communication to an audience [11].

Advocates of the Communicative Language Teaching (CLT) approach and guided discover learning distinguish drama techniques which are extremely popular in teaching English as a second language (TESL). Drama is considered a technique to engage learners in active learning and interactive pedagogy which encourages them to 


\section{Теория и методика профессионального образования}

engage in dialogue which uses subject specific language in highly appropriate contexts. In CLT drama techniques play an important part because of their holistic effect on the personality development. CLT enables teachers to create studentcentered, communicative environment which implies simulation of communicative situation, role distribution, problem statement and problem solving. Drama techniques are widely used in role-plays, simulation and language games which cause physical and emotional activity, foster imagination and improvisation [7].

According to our point of view drama techniques in FLT are considered as a combination of procedures that organize learner's role-related behavior in specially designed game situations promoting to develop both communicative competence and student's personality as a whole. While drama method may be regarded as a holistic approach to FLT, that encompasses a set of drama techniques engaging students into communicative purposeful activity, where the learner rather than the language or indeed the teacher is at the centre of the learning process.

\section{Statement of the Problem}

The current study is aimed to find answers to the following question: How does using drama technique in TESL affect the learner development?

\section{Review of Literature}

The results of the literature review made it possible to point out both advantages and challenges that bring drama into FLL and FLT. First of all, drama is regarded as a valuable tool for language teachers because it stimulates students' further (proximate) development and it holds their potential for learning. According to Vygotsky's concept of the "zone of proximal development" "learning" and linguistic development are both communally driven. There we may conclude that drama method with its social interaction can be regarded as a key, providing "the basis for internalization and consequently development" [1].

Via and some other researchers considered the value of drama in language teaching derived from the opportunities it provides the students to have a meaningful purpose to express themselves $[4,10]$. The development of the awareness of the use of a language in different environment and situations builds self-confidence, creativity, spontaneity, improvisation and involving emotions of the participants. It encourages the natural use of a foreign language according to the particular situation. The learners' experience of using a language in the classroom becomes similar to the real-life experience. In other words, students learn through direct experience.

The drama teaching method (DTM) allows the creation of contexts for different language uses. In both FLT and drama, context is often thought to be everything. Drama can generate a need to speak through a context that appeals to the students. It stimulates them to reveal their creative potential and to apply their artistic talents. Students become more motivated, they experience a sense of achievement and this reinforces their learning. The real world provides speakers with a variety of contexts. Using drama makes it possible to transform a traditional learning space into a meaningful environment: an office/airport/ restaurant/ garden/court etc. Thus context is provided with the option of a wide range of vocabulary and a number of situations to practice the foreign language. So, this is a meaningful context that is one of the most recognizable benefits of using DTM which allows to prepare the student for communication in real-life situations.

In respect to the language skills, its prime value lies in learning speaking and listening. Drama encourages concentrated listening. Students have to listen very carefully when they act, so that they can react as the situation requires it. So, these two activities are interrelated. Moreover, drama provides context for listening. Listening exercises may include listening to music, news, TV programmes, movies, telephone calls, small talks, directions, announcements and many more. All these can be easily linked with drama activities. The presence of drama and its techniques is an ideal tool to stimulate and carry on different speaking activities with the focus on fluency, pronunciation, stress, intonation etc. It provides a field for sufficient practice in acquiring the language skill. Among those are writing poetry, a story, a narrative, a play, a role play, a scene, a song, an advertisement, different kinds of letters and postcards etc. They essentially involve the use of imagination and creativity.

Besides, one can also pay attention to the advantage of drama in developing student's writing skills. Through drama writing activities students may gain deeper understanding of the need to master their writing skills as they act out situations when writing is necessary and even inevitable. 
It is noteworthy, that the use of drama develops students' reading skills as well. The examples of those are newspapers, magazines, cartoons and advertisements, all of these can be used for dramatization. All in all, using drama techniques in FLT and FLL has a profound effect on students' learning experience. It suggests improvisation with the language with the help of imagination and creativity of a learner.

Drama techniques greatly contribute to developing social skills and interaction, as well. To take part in drama, students must interact and strive to understand each other. It helps to overcome social and linguistic barriers in effective communication. Therefore, drama techniques provide students with situations that demand leaners' ability to collaborate or to work in a team.

Moreover, using drama can be enjoyable; it creates an atmosphere conducive to learning and helps to overcome two main obstacles for learners in spontaneous speech: the fear of making mistakes and the fear of using the foreign language in front of others.

Thus, using drama techniques in ESL results in [2]:

- making FLL active, motivating experience where students can express naturally and spontaneously via verbal and non-verbal means;

- helping learners gain the confidence and self-esteem as it helps the students cope with real-life situations;

- focusing on the basic communication, linguistic and social skills required for students to participate in drama activities;

- developing linguistic and communicative competence through using Grammar and Vocabulary in a meaningful context;

- creating friendly and cooperative atmosphere enhancing the development of students' ability to work together as a team or group, learning to be empathetic and tolerant, sharing responsibility etc.

What really important is that using drama techniques allows to change the roles of learners and teachers, create better rapport between a teacher and his or her learners, motivate both learners and teachers.

\section{Forms of drama activities}

in a foreign language class

There are a lot of drama-based activities that could be introduced either in or out of classrooms. Drama games (ice-breakers, warm-ups, fillers, concentration games), guided improvisation (a scene of a crime, a company meeting, a summer camp at night etc.), prepared improvised drama (when students themselves work and perform a story, a situation or a number of situations), mime ("a non-verbal representation of an idea or story through gesture, bodily movement and expression" [5]), improvisation (helps learners to discover their own resources from which their most imaginative ideas), simulation (a problem-solving activity to which the student brings his own personality, experience and opinions or an interaction activity with various categories of dialogues [9]) and role-play (students either improvise or create their own character or they are given role-cards). So, dramatic activities can be very different and can vary from songs, rhymes and chants, and miming to role-play and improvisation according to the age and level of the target group.

Drama is based on the humanistic approach to education which gives teachers enough opportunities to practice facilitative roles in the classroom: an initiator, a counsellor, an encourager, a supporter, a monitor, a participant, a prompter, a co-communicator, a cooperator and so on. These roles do not mean the loss of discipline or the loss of authority. They give teachers the opportunity to like their job and their learners, and see their learners as creative and resourceful human beings with real needs, wants and drawbacks [2].

Here are some tips on how to accept the facilitative roles of a foreign language teacher:

1. Become your learners' partner but be respected at the same time.

2. Listen to your learners attentively and be responsive to them.

3. Accept your learners' opinions and suggestions.

4. Respect your learners' feelings and emotions.

5. Encourage them, don't discourage them.

6. Help them raise their self-esteem and increase their confidence.

7. Model how to function and cooperate in a community.

8. Get to know about your learners' learning styles, strategies and motivation.

9. Reveal the hidden creativity of your learners.

10. Participate in activities and cooperate. [2, p. 24-25].

Tasks and challenges

DTM requires clear understanding of the drama activity procedure. First, the proper intro- 


\section{Теория и методика профессионального образования}

duction of the activity is needed at the beginning, clearly communicating to the students the goal and the tasks of the activity. They should also be aware of the background, roles, rules, potential difficulties, timing etc. Then, teachers need to decide how to evaluate students' activity, make corrections and provide feedback. It is important for teachers to realize, that it is students who are actively involved in learning and the role of the teacher in this process is not a central one. FLT should be learner-centred.

However, alongside with all the benefits mentioned above, supporters of DTM argue that it brings a number of challenges for the teacher. First of all, it involves moving away from familiar structures and routines towards the approaches that are more open-ended and unpredictable. Secondly, with older learners there may be problems of inhibition and embarrassment. Besides, in the context of TESL, the possibilities are inevitably limited by the fluency and language facility of the learners. Moreover, since every learner is a unique personality with a different social (sometimes even cultural) background, it is quite challenging for a teacher to create a community of learners in a class who respect, support and encourage each other. The different personalities of learners make the socializing process quite demanding. There always are learners who prefer working on their own [2, p. 24]. However, in real life there are daily activities and situations where people have to share, cooperate and help each other in order to survive in society, that's why the use of DTM could be admitted as a powerful tool which enables learners to cope with these problems and anxieties.

With DTM one of the biggest problems of mixed ability could be reduced. Students who are more fluent can take the main roles which require more oral communication, while the weaker students compensate for their lack of linguistic ability by paralinguistic communication e.g. body language and general acting ability (miming). In other words, a teacher can apply the principle of differential education in groups with different levels of language knowledge that is a real challenge.

\section{Methodology}

Most of the benefits listed above apply also to teaching of languages for professional/special purposes. Learning by doing/through communicating has been one of the fundamental themes of twentieth century education. The authors of the article suggest that drama techniques may be effective in teaching ESP (English for Special Purposes) in a number of ways.

We believe that assuming occupational roles helps students better understand their future professional field. Drama makes them to focus on the language of professional discourse. It gives students the unique opportunity to enlarge their vocabulary and then to practice it on the spot in different profession-related activities such as meetings, making appointments, business dinners, trials, conferences, meeting delegations, interviews, etc.

Besides, it provides the learners with the situation that helps to develop their personal qualities required to carry out professional duties. Drama techniques can show students - e.g. future lawyers - the importance of emotions in professional contexts.

\section{Role play as the form of DTM}

In FLT role-plays can serve as a multifaceted educational platform for implementing skills in practice and developing a set of professional competences. Those required by the State Federal Standard of Higher Professional Education to future lawyers are: the ability to carry out professional duties based the developed legal consciousness, legal thinking and legal culture, the ability to make decisions and perform legal actions in strict accordance to the law, commitment to keep law and order, safeguard the individual, society, state, etc [6].

In FLT role-play as a technique should practice [2]:

- conversation skills of a character in a specific role (how to start, lead and finish a dialogue, how to express oneself even with limited knowledge of vocabulary and grammar);

- nonverbal communication through mime, gestures, facial expressions and body posture (how to express the status of the character through body language, how to express meaning through mime, how to understand and react to the body language of other cultures);

- awareness of otherness (how to understand others' feelings and motives for acting, how to share others' attitudes);

- self-awareness (how to gain confidence, how to become accepted and understood);

- creativity (how to communicate in unpredictable situations, how to solve unexpected problems);

- social skills (how to socialize, how to negotiate, how to approach people).

In order to achieve the desired effect in using 
the role-play as a technique in FLT the following steps should be taken into account by the participants of the play.

1. Preparation stage - creating:

- characters - who they are?

- place - where they are?

- the purpose of their communication why they are talking together?

- content- what they are talking about?

2. Production stage involves performing role-plays where learners in roles act as somebody else in an imaginary situation.

3 . Reflection stage is the final stage of a roleplay where learners and teachers together are expected to provide feedback on the quality of performed role-plays. The language used, creativity of learners in roles and their motives to act in certain ways are possible issues to be discussed and reflected on in a class.

Another important issue is the criteria according to which the role play may be evaluated in terms of its effect on the FLT process. Nowadays different types of role-plays are commonly integrated into language course books. A welldesigned role-play should be tailor-made. It should be:

- appropriate to the age level of learners and their life experience (a teenage learner would be unable to book a flight ticket without personal life experience);

- adjusted to the proficiency level of learners (the task should be clearly formulated and it should require the use of known words; it should require language appropriate to the age and proficiency level of learners);

- communicative (there should be a reason to start a dialogue, negotiate and exchange information via applying different language functions);

- manageable in a given time limit (it should not be either too simple or too demanding to accomplish);

- well-designed (1. there should be enough information about characters- who they are, what their relationship is to each other, what they are like, what they feel like, 2. description of setting where the conversation happens, 3. moment of surprise - a twisting element in a dialogue where something unexpected happens) [2, p. 52-53].

\section{Experiment}

At the Foreign Languages Department of South Ural State University using drama techniques in FLT process is one of the ways to involve students into purposeful highly motivated activity. One of the examples is "Mock trial", a role play that is annually performed by the students of the Law Faculty and teachers of Foreign Languages Department (SUSU). Role-plays enable both teachers and learners to look at the situation from a different perspective through personal experience. Since role-playing is quite a complex form of DTM, it needs careful planning, designing and preparation. A role-play should be preceded by a set of activities where characters, their actions and setting are described or invented. Role-plays should respect age, proficiency level and the interests of learners.

Mock Trial as a kind of a role play has its own educational advantages and benefits. First, each participant practices his/her conversational skills of a character in a specific role: a judge, or a prosecution/defence attorney, or a bailiff, or defendant, etc. presupposes definite and strictly designed forms of expressions, clichés, stipulated by the required protocol of the trial. All the vocabulary and grammar structure to be used are the subject to traditions and protocol. The judicial system of the United Kingdom and the USA is full of traditions and protocol.

As Mock Trail is a live process, nonverbal means of communication, i.e. mime, gestures, facial and body language help the actors to express the status of the character, his/her educational and social background, physical and emotional state at the trial. Moreover, because the situation itself is unpredictable participants of the trial have to face some unexpected problems that need solution. Mock Trial is an open court trial with the uncertain end: nobody knows whether the case will be won or lost, so it demands all the participants' creativity and being on alert. This unpredictability is a great demanding feature, a real challenge and at the same time a powerful educational benefit as all this results in development of communicative, linguistic and social skills of the students.

During the first stage (preparation) students are welcome to choose the characters they would like to play: judges, attorneys, a defendant, a bailiff, jury, witnesses for the prosecution and the defence, forensic experts, etc. They have to look into the case and thoroughly examine all the details of the crime: the characters, their state, place, time, conditions, reasons, etc. Then they have to work out the strategy of the defence/prosecution together with witnesses and a defendant; to think over possible questions for direct and cross 


\section{Теория и методика профессионального образования}

examination, to prepare forensic expert examinations, physical evidence, etc.

At the second stage - production - Mock Trial is performed where all the participants' skills and abilities are likely to be realized and manifested. Carefully prepared part of the performance (opening and closing statements of the defence/prosecution attorneys, for example) should be gently mingled with the spontaneous, unintended part of the live case hearing (cross examinations, questions of the judge, the verdict of the jury). This stage of the role play is extremely important for it is the time when students have to show everything they had prepared during the first stage: awareness of peculiarities of the Anglo-American legal system, the protocol of the trail, features of judicial rhetoric, rules of conduct during the trial, etc. Besides, they should cope with excitement or quiver and demonstrate their ability to express themselves according to the role the play (intonation, tempo of the speech, mime, facial and body language and so on), to react and change the scenario if it's required by the invented storyline, to keep the situation under control.

The final stage of the Mock Trial - reflection provides feedback on the mistakes and drawbacks that occurred during the previous two stages; different ideas and thoughts related to the organization and performance of the trial are discussed, feelings and emotions are shared; suggestions for future drama activities are put forward. The results are summed up.

\section{Results}

After role plays or other drama-based activities teachers ask the students to evaluate the importance and the results of their participating in such kinds of activities. According to the results of the survey conducted by the FLD all the participants enjoyed taking part in drama activities (100\% of respondents). The benefits of using drama techniques may be summarized as follows: (63\%);

1) increase of motivation (interest) in FLL

2) opportunity to reveal student's creative potential $(54 \%)$;

3) opportunity to self-express (38\%);

4) ability to work in a team (42\%);

5) development of intercultural communicative competence $(68 \%)$.

The students were also asked to share their feelings after the play in the written form. Students praise drama techniques on being very beneficial in terms of the creative atmosphere that helped to realize English not as an academic discipline but as a tool of art. One of the students mentions that with drama techniques in FLL alongside with the development of intercultural communicative competence she acquired the skills to express herself positively, developed her acting abilities, managed to reveal her creativity. Others mentioned that with drama they enlarged their professional vocabulary, acquired the skills to analyze, compare, discuss, contradict, put forward suggestions, reject or agree. All of the participants point out that they become more independent and responsible in FLL.

\section{Conclusion}

The results of the research show that in FLL drama techniques may be regarded as a means to acquire linguistic and non-linguistic competences valuable for learner's future professional sphere. They can be used to teach grammar, pronunciation, vocabulary, intercultural aspects, and socalled soft skills such as presentation competence, teamwork skills and self-management. They can create memorable and practice-oriented learning experiences that improve learners' language-competence, employability and personal development. Therefore, drama should not be regarded as merely an enjoyable out-of-class activity but as a teaching method that involves the learners into meaningful productive activity. In drama the students learn by doing, thus foreign language is acquired subconsciously and students become more confident in their use of English by experiencing the language in operation.

\section{References}

1. Barohny E., Hye-Soon L. A Sociocultural View of Language Learning: The Importance of Meaning-Based Instruction. TESL Canada Journal, 2009, pp. 13-26.

2. Billikova A., Kiššova M. Drama Techniques in the Foreign Language Classroom. London, Nitra, 2013.

3. Davies P. The Use of Drama in English Language Teaching. TESL Canada Journal Revue, TESL DU, 1990.

4. Dodson S.L. The Educational Purpose of Drama for ESL. G. Brauer Içinde, Body and Language: Intercultural Learning Through Drama. Greenwood, 2002, pp. 161-175.

5. Dougill J. Drama Activities for Language Learning. London, Macmillan Publishers, 1994.

6. Federal State Educational Standards of 
Higher Education. Available at: http://www. fgosvo.ru/ (accessed 15.12.2015).

7. Fleming M. "Drama" in Byram. M. (ed.) Encyclopedia of Language Teaching and Learning. London, Nitra, 2013.

8. Fleming M. Starting Drama Teaching. London, David Fulton Publishers, 2003.
9. Livingstone C. Role Play in Language Learning. Harlow, Longman, 1983.

10. Via R. Drama \& Self in Language Learning. The English Teaching Forum, 1985, pp. $12-15$.

11. Way B. Development Through Drama. London, Longman, 1967.

Received 16 December 2015

УдК $378.147+811.111$

ББК Ч448.027 + Ш143.21

DOI: $10.14529 /$ ped160108

\title{
ДРАМАТИЗАЦИЯ В ОБУЧЕНИИ АНГЛИЙСКОМУ ЯЗЫКУ КАК ИНОСТРАННОМУ В УНИВЕРСИТЕТЕ
}

\author{
Е.Г. Шрайбер, Е.Н. Ярославова \\ Южно-Уральский государственный университет, г. Челябинск
}

\begin{abstract}
Статья посвящена важности использования приемов драматизации в обучении английскому языку как иностранному в университете. Драматизация создает основу для взаимосвязанного формирования лингвистических и социальных навыков обучающихся наряду с развитием их личности и способностей. Основная цель статьи - раскрыть преимущества применения метода драматизации в обучении иностранным языкам. Особое внимание уделяется ролевым играм, как одной из наиболее продуктивных технологий, использующих метод драматизации. Основные методы исследования - обзор научной литературы, анализ периодических изданий, наблюдение и опрос. Авторы статьи рассматривают использование метода драмы как неотъемлемую составляющую профессионального обучения студентов и знакомят читателя с результатами эксперимента - ролевой игры, проведенной на юридическом факультете в форме игрового судебного процесса (Mock Trial).

Ключевые слова: прием драматизации, изучение и обучение иностранному языку, ролевая игра, игровой судебный проиесс.
\end{abstract}

Шрайбер Елена Григорьевна, кандидат педагогических наук, доцент кафедры иностранных языков, Южно-Уральский государственный университет, г. Челябинск, shraibereg@susu.ru.

Ярославова Елена Николаевна, кандидат педагогических наук, заведующий кафедрой иностранных языков, Южно-Уральский государственный университет, г. Челябинск, yaroslavovaen@, susu.ru.

Поступила в редакцию 16 декабря 2015 2.

\section{ОБРАЗЕЦ ЦИТИРОВАНИЯ}

Shraiber, E.G. Drama techniques in teaching english as a second language to university students / E.G. Shraiber, E.N. Yaroslavova // Вестник ЮУрГУ. Серия «Образование. Педагогические науки». - 2016. - Т. 8, № 1. C. 59-65. DOI: $10.14529 /$ ped 160108

\section{FOR CITATION}

Shraiber E.G., Yaroslavova E.N. Drama Techniques in Teaching English as a Second Language to University Students. Bulletin of the South Ural State University. Ser. Education. Educa-tional Sciences. 2016, vol. 8, no. 1, pp. 59-65. DOI: $10.14529 /$ ped 160108 